\title{
KONSTRUKSI INFORMASI POLITIK \\ (STUDI KASUS PADA MASYARAKAT KOTA CIMAHI PASCA PENETAPAN CALON WALIKOTA DAN WAKIL WALIKOTA DALAM PILKADA SERENTAK )
}

\author{
Adiyana Slamet \\ Program Studi Ilmu Komunikasi, Fakultas Ilmu Sosial dan Ilmu Politik \\ Universitas Komputer Indonesia \\ Adiyana.slamet@email.unikom.ac.id
}

\begin{abstract}
The consolidation of local democracy will be realized well if the political information provided by the electoral institutions and political institution through political communication can encourage people to get a 'nutrition' receive political information, so they can learn about politics. Political information in simultaneosly election is part of candidate "candidates pair" a Mayor Cimahi City can do political communication for competing to provide on political information about prospective policy choice that will be submitter later. When the political information of the citizen is fulfilled, the citizen can choose with a large responsibility and rationally to choose leader in their area, based on considerations that the common benefit of the people themselves. In 2017 is a political year for 101 regions that held the head simultaneous elections (Pilkada) throughout in Indonesia. There are 7 Provinces, 76 District and 18 Cities that participate in the simultaneous elections. One of the 18 cities that held the elections was Cimahi City. Cimahi City has a permanent voter list of 375,722 people who use its sovereignty to elect a Mayor candidate who will lead the region for the next 5 years. In the party of democracy, it is fundamental that political information becomes a reinforcement in political cognition that will be implemented in the space of political participation itself. Political education is an obligation for political organizers, especially for the General Election Commision (KPU) Cimahi City and Political Parties to provide political information to the public.
\end{abstract}

\section{Keywords: Political Communication, Political Information, Cimahi City,} Simultaneous Election.

\begin{abstract}
Abstrak
Konsolidasi demokrasi lokal akan terwujud dengan baik jikalau informasi politik yang diberikan oleh institusi penyelenggara pemilu dan institusi politik melalui proses komunikasi politik dapat mendorong rakyat mendapatkan 'gizi' menerima informasi politik sehingga belajar tentang politik. Informasi politik dalam pilkada sentak merupakan bagian dari bagaimana kandidat "pasangan calon" Walikota Cimahi melakukan komunikasi politik untuk berlomba-lomba memberikan informasi politik mengenai prospective policy choice yang akan di usung nantinya. Ketika informasi politik masyarakat itu terpenuhi, tentu masyarakat bisa memilih dengan tanggung jawab besar secara rasional untuk memilih pemimpin di daerahnya berdasarkan pertimbanganpertimbangan yang "menguntungkan" kepentingan rakyat itu sendiri. Tahun 2017
\end{abstract}


menjadi tahun politik bagi 101 daerah yang menggelar pemilihan kepala daerah (Pilkada) Seretak di seluruh Indonesia. Terdapat 7 Provinsi, 76 Kabupaten dan 18 Kota yang mengikuti Pilkada serentak tersebut. Salah satu dari 18 Kota yang menggelar Pilkada tersebut adalah Kota Cimahi. Kota Cimahi memiliki daftar pemilih tetap sejumlah 375.722 orang yang menggunakan kedaulatannya untuk memilih pasangan calon Walikota yang akan memimpin daerahnya selama 5 tahun kedepan. Dalam pesta demokrasi menjadi hal fundamental bahwa, informasi politik menjadi penguat dalam kognisi politik yang nantinya di implementasikan pada ruang partisipasi politik itu sendiri. Pemberian informasi politik merupakan sebuah kewajiban bagi penyelenggara pemilu terutama KPU Kota Cimahi dan Partai Politik untuk memberikan Informasi politik kepada masyarakat.

Kata Kunci: Komunikasi Politik, Informasi Politik, Kota Cimahi, Pilkada Serentak

\section{PENDAHULUAN}

Reformasi di bidang politik membawa perubahan besar dalam kehidupan demokrasi di Indonesia, misalnya saja pemilihan kepala daerah (Pilkada) yang sebelumnya di pilih oleh Dewan Perwakilan Rakyat Daerah (DPRD) menjadi dipilih langsung oleh rakyat. Penguatan pengetahuan politik pemilih supaya menjadi pemilih rasional dan akan berimbas pada kualitas Pemilihan Kepala Daerah serentak di Kota Cimahi 2017 tidak lain dari bagaimana usaha pendapatkan informasi politik yang diterima oleh pemilih dalam kontestasi Pemilihan Kepala Daerah serentak yahun 2017 di Kota Cimahi. Pemilihan Kepala Daerah di Kota Cimahi merupakan Objek politik yang kemudian terdapat aktifitas, ada yang memberi informasi politik dan ada yang menerima informasi itu. Aktivitas politik adalah serangkaian kegiatan yang berlandaskan pada pengumpulan, analisis dan penggunaan informasi politik yang diterima. (Firmanzah, 2010:140). Perhelatan kontestasi 5 tahunan Pilkada serentak gelombang kedua yang dilaksanakan 15 Februari 2017 sudah seharusnya menjadi ajang bagi para kandidat pasangan calon ataupun perseorangan sebagai ajang untuk berlomba-lomba memberikan informasi politik mengenai prospective policy choice atau kebijakan yang akan diusung untuk 5 tahun kedepan dalam menahkodai daerah yang dipimpinnya. Kota Cimahi menjadi salah satu dari 18 kota yang melaksanakan Pilkada serentak tahun 2017 dengan 375.722 daftar pemilih yang akan menggunakan hak politiknya untuk memilih kepala daerah yang selama 5 tahun kedepan akan memimpin di Kota Cimahi.

Dalam konsepsi Effendi Gazali (2010) Komunikasi politik dalam pemilu diasumsikan, Komunikasi berisi informasi dan citra (kesan); (2) Informasi dalam Komunikasi Politik sama dengan Prospective Policy Choices (apa-apa saja kebijakan yang menguntungkan pemilih kalau memilih seorang kandidat), dan (3) Citra dalam Komunikasi Politik sama dengan Image Making (penguatan kesan atau memori bahwa seorang calon memang akan melaksanakan apa yang ia janjikan). Jadi Komunikasi Politik dalam Pemilu sama dengan Kompetisi memberikan informasi tentang kebijakan seorang kandidat yang menguntungkan pemilih plus perlombaan membuat citra yang 
tertanam dimemori pemilih bahwa seorang kandidat akan lebih melaksanakan janjinya dibanding calon lain.

Sebagaimana Penetapan nomor urut dan daftar nama pasangan calon pada pemilihan Walikota dan Wakil Walikota pada Pilkada Serentak di Kota Cimahi yag ditetapkan melalui Surat Keputusan KPU Kota Cimahi Nomor 201/kpts/KPU Kota Cimahi/011.329201/x/2016 dan menghasilkan Tiga Nomor Urut pasangan calon yang mengikuti gelaran Pilkada serentak di Kota Cimahi yakni nomor urut 1 . Hj. Atty Suharti, SE dan Ir. H. Achmad Zulkarnain, MT, Nomor urut 2. H. Asep Hadad Didjaya, SH,SE., MM dan dr. R. Adj. Irma Indriyani, dan Nomor Urut 3. Ir.H AjayMuhhamad Priatna, MM dan Letkol (Inf) Ngatiyan. ketiga Pasangan Calon tersebut tentunya akan berkompetisi merebut hati pemilih untuk dapat memenangkan pemilihan kepala daerah di Kota Cimahi.

Menurut Kumolo Pilkada kini lebih menarik dibincangkan banyak orang, khususnya sejak diselenggarakan secara langsung. Perbincangan yang dimaksud adalah tentang hal ihwal calon kepala daerah dan wakilnya. Lebih jauh, sinyalemen sementara, masyarakat mulai meyakini hubungan kepemimpinan daerah terhadap perikehidupan mereka sendiri dari kepala daerah yang dipilih. Ini mengiindikasikan, di satu sisi, dinamika demokrasi lokal memberi sinyal positif bahwa masyarakat makin dewassa berpolitik walaupun yang menjadi perhatian dalam sejarahnya adalah janji atau program-program calon kepala daerah dan wakil kepala daerah. (Kumolo 2017:79)

Oleh karena itu, pemerintah, sejak awal reformasi, terus memperbaiki kualitas penyelenggaraan pemerintahan yang diarahkan untuk mewujudkan tata kelola negara yang demokratis. Salah satu upaya yang dilakukan pemerintah adalah dengan melaksanakan berbagai perubahan atas undang-undang bidang politik dan pemerintahan. Perubahan terhadap undang-undang ini dilakukan agar proses penyelenggaraan pemerintahan dari yang awalnya sentralistik berubah menjadi desentralistik agar terwujud mekanisme pemilihan kepala daerah (pilkada) yang sesuai dengan kehendak rakyat, yaitu penyelenggaraan pilkada langsung. (Kumolo, 2017 : 79-80)

Pelaksanaan pilkada langsung secara serentak ini menunjukan bahwa Indonesia tengah memasuki babak baru menuju good governance dan clean government yang saling bersinergi dengan Nawa Cita dan pembangunan daerah. Proses demokrasi yang berlangsung di daerah merupakan siklus awal dari perencanaan pembangunan menyangkut hajat kepemimpinan untuk mendapatkan visi pembangunan. Keberhasilan perencanaan pembangunan hingga ke siklus penganggaran, pelaksanaan, dan evaluasi ditentukan dari hasil proses demokrasi lokal. Proses penguatan demokrasi ini akan memperkuat legitimasi pemerintahan dari rakyat memalui terpilhnya pemimpinpemimpin yang berkualitas baik di pusat maupun di daerah. (Kumolo, 2017: 80)

Adapun, penguatan demokrasi di tingkat lokal akan menjamin mutu kepala daerah untuk dapat merencanakan kebijakan pembangunan yang efektif dan efisien. Jika masyarakat dapat memberikan sumbangsih besar pada daerahnya dengan aktif dan partisipatif pada 
pilkada, maka awal yang baik dari proses perencanaan pembangunan sudah dapat dipastikan. Singkatnya, pelaksanaan pilkada serentak telah membangun budaya politik baru dengan kebebasan yang beradab dalam demokrasi Indonesia.

Wacana awal menurut UndangUndang Nomor 22 Tahun 2014 tentang Pemilihan Gubernur, Bupati, dan Walikota, yang ditetapkan oleh DPR RI Periode 2009-2014, mekanisme pilkada dilakukan oleh DPRD. Namun, wacana ini mendapatkan penolakan dari rakyat, konsekuensinya Undang-Undang Nomor 22 Tahun 2014 tidak jadi diterapkan dan diganti dengan UndangUndang Nomor 1 Tahun 2014 tentang Pemilihan Gubernur, Bupati, dan Wali Kota, yang mengatur mekanisme pilkada secara langsung oleh rakyat. Baru kemudian pada masa pemerintahan kabinet kerja terjadi pembahasan bersama antara pemerintah dan DPRD RI dengan hasil pembahasannya adalah Undang-Undang Nomor 1 Tahun 2015 tentang Penetapan Peraturan Pengganti Undang-Undang Nomor 1 Tahun 2014 tentang Pemilihan Gubernur, Bupati, dan Wali Kota Menjadi Undang-Undang.

Undang-Undang ini kemudian digantii menjadi Undang-Undang Nomor 8 Tahun 2015 tentang Perubahan atas Undang-Undang Nomor 1 Tahun 2015. Namun, Sejumlah ketentuan dalam Undang-Undang ini mendapat gugatan ke Mahkamah Konstitusi sehingga putusan Mahkamah Konstitusi menjadi acuan dalam pelaksanaan pilkada serentak pada 9 Desember 2015. Guna mengakomodasi putusan Mahkamah Konstitusi kedalam ketentuan undang-undang pilkada dan dalam rangka persiapan pelaksanaan pilkada serentak tahap kedua pada 15
Februarii 2017, maka pemerintah bersama DPR RI kembali menetapkan Undang-Undang Nomor 10 Tahun 2016 tentang Perubahan Kedua atas UndangUndang Nomor 1 Tahun 2015. (Kumolo, 2017: 81). Dengan demikian, Pemilihan Umum Kepala daerah secara langsung telah memberikan makna yang sangat dalam pada perkembangan komunikasi politik di Indonesia. Tentunya komunikasi politik menunjukan arah yang jelas pada pencapaian informasi politik yang dapat berupa pendidikan politik, sosialisasi politik, hingga bermuara pada partisipasi politik.

\section{METODE}

Metode penelitan menjadi penting, karena pada metode berperan sebagai pisau bedah dari suatu penelitian, dimana akan menemukan akar dari permasalahan dari suatu objek penelitian dengan suatu cara tertentu. Selain itu, dengan metode juga pada nantinya akan menemukan jawaban atau kesimpulan dari objek penelitian. Metode yang digunakan oleh peneliti adalah metode penelitian kualitatif, dimana penelitian kualitatif merupakan metode yang didasarkan pada interpretasi penulis atau peneliti. Pemilihan metode yang digunakan harus dapat mencerminkan relevansi hingga metode yang digunakan dalam penelitian agar berjalan beriringan yang kesemuanya itu harus sesuai pula dengan permasalah yang di angkat dalam penelitian. Dalam Penelitian ini peneliti menggunakan pendekatan kualitatif dengan desain studi kasus (case studies), mengacu pada John W.Creswell dalam bukunya Qualitative Inquiry and Research Design: Choosing Among Five Tradition bahwa studi kasus sebuah eksplorasi dari suatu 
sistem yang terikat atau suatu kasus/beragam kasus yang dari waktu ke waktu melalui pengumpulan data yang mendalam serta melibatkan berbagai sumber informasi yang kaya dalam suatu konteks. (Creswell, 2014).

Pendekatan kasus yang diamati yakni Konstruksi Informasi Politik studi kasus pada masyarakat Kota Cimahi pasca penetapan calon Walikota dan Wakil Walikota dalam Pilkada serentak 2017. Dalam penelitian ini peneliti berusaha untuk mengamati, memahami dan menganalisis bagaimana konstruksi Informasi Politik pasca penetapan calon Walikota dan wakil Walikota Kota Cimahi dalam gelaran Pilkada serentak 2017. Salah satu karakter penelitian kualitatif adalah melakukan pengamatan dan berinteraksi dengan subyek penelitian untuk berusaha memahami bahasa dan tafsiran mereka atas dunianya. Penelitian ini dilakukan pada tanggal 28 Oktober 2016 sampai 15 januari 2017. Dalam peneliti ini penentuan informan dengan menggunakan teknik snow ball dan purposive sampling, dimana teknik ini mencakup orang-orang yang diseleksi atas dasar kriteria-kriteria tertentu yang dibuat peneliti berdasarkan tujuan penelitian. (Kriyantono, 2007:154) Menurut Creswell kriteria informan yang baik adalah: "all individuals studied represent people who have experienced the phenomenon" (Creswell, 1998: 118). Jadi, lebih tepat memilih informan yang benar-benar memiliki kapabilitas karena pengalamannya dan mampu mengartikulasikan pengalaman dan pandangannya tentang sesuatu yang dipertanyakan. Maka informan dalam penelitian ini sebanyak 330 orang yang tersebar di 15 Kelurahan.
Data dalam penelitian ini bersumber dari data primer dan data sekunder. Data primer bersumber dari informasi yang diberikan oleh para informan sebagai subjek penelitian melalui wawancara mendalam yang dilakukan di 15 kelurahan. Selain itu juga bersumber dari observasi atau serangkaian pengamatan yang dilakukan oleh peneliti terhadap Konstruksi Informasi Politik pada Masyarakat Kota Cimahi Pasca Penetapan Calon Walikota dan Wakil Walikota dalam Pilkada Serentak 2017.Data sekunder adalah data yang diperoleh dari berbagai sumber yang berhubungan dengan hal-hal yang diteliti berupa buku, majalah, surat kabar, jurnal, disertasi, kliping, serta literatur-literatur lainnya yang berkaitan dengan masalah penelitian. Selain itu pengumpulan data juga bersumber dari observasi atau serangkaian pengamatan yang dilakukan oleh peneliti terhadap Konstruksi Informasi Politik pada Masyarakat Kota Cimahi Pasca Penetapan Calon Walikota dan Wakil Walikota dalam Pilkada Serentak 2017.

Data sekunder adalah data yang diperoleh dari berbagai sumber yang berhubungan dengan hal-hal yang diteliti berupa buku, majalah, surat kabar, jurnal, disertasi, kliping, serta literatur-literatur lainnya yang berkaitan dengan masalah penelitian. Menurut peneliti prosedur pengumpulan data secara langsung dengan melakukan wawancara, observasi sebagai data primer dalam penelitian kualitatif sebagai konsekwensi yang peneliti harus ambil untuk menggali data dan infromasi pada subjek penelitian agar mendapatkan data titik jenuh disamping data sekunder yang peneliti dapat melalui pengumpulan dokumen dan perekaman audio visual dilapangan, 
serta peneliti juga memilih Pengumpulan data dilakukan secara langsung melalui proses wawancara dengan informan, mengamati perilaku mereka, juga didukung oleh data sekunder berupa literature dan sumber data penunjang, dimana satu sama lain saling menunjang dan melengkapi.

Selain itu, aktivitas pengumpulan data yang peneliti lakukan mengacu pada aktivitas pengumpulan data dari Creswell yaitu "A Data Collection Circle" (Creswell, 1998:109-135). Aktivitas yang dilakukan dengan model Creswell memperlihatkan bahwa satu sama lain saling berhubungan, diawali dengan penentuan tempat atau individu. Pada model "A Data Collecting Circle" dari Creswell, proses pendekatan ini disebut sebagai "Gaining Access and Making Repport" atau proses pendekatan. Uji keabsahan data dalam penelitian kualitatif meliputi beberapa pengujian. Uji keabsahan data ini diperlukan untuk menentukan valid atau tidaknya suatu temuan atau data yang dilaporkan peneliti dengan apa yang terjadi sesungguhnya di lapangan. Berikut adalah teknik pemeriksaan keabsahan data penelitian yang dikemukakan Moleong (2005:327-339) sebagai berikut.

1. Triangulasi, teknik pemeriksaan keabsahan data yang memanfaatkan sesuatu yang lain.

2. Diskusi dengan rekan sejawat, untuk meningkatkan keakuratan hasil penelitian.

3. Pemeriksaan anggota, yaitu peneliti mengumpulkan pandangan dari para partisipan tentang kredibilitas dari temuan dan penafsirannya. (Creswell, 2014:350)

Teknik analisis data yang peneliti pakai dalam penelitian ini ialah analisis data kualitatif. Menurut Miles dan Huberman (1984) menjelaskan bahwa analisis data terdiri dari :

1. Pengumpulan Data (Data Collection) yakni merupakan kegiatan pengumpulan data-data yang ada terlebih dahulu. Semua informasi penting yang terkait dengan masalah penelitian ini, selanjutnya data itu dikelompokkan sesuai dengan topik permasalahan.

2. Reduksi Data (Data Reduction) merupakan kegiatan mereduksi data-data yang diperoleh setelah dilakukan pengumpulan dengan suatu bentuk analisis yang menajam, menggolongkan, mengarahkan, membuang data yang tidak diperlukan dan mengorganisasi data.

3. Penyajian Data (Data display) merupakan kegiatan memperlihatkan data yang diperoleh setelah direduksi terlebih dahulu.

4. Penarikan kesimpulan atau tahap verifikasi (Conclusing drawing \& verification) merupakan kegiatan membuat kesimpulan dengan menggambarkan atau memverifikasi data-data yang diperoleh. Tahap ini dimaksudkan untuk menghindari kesalahan interpretasi dari hasil wawancara dengan sejumlah informan penelitian yang dapat mengaburkan makna persoalan sebenarnya dari fokus tentang penelitian ini.

Tahapan-tahapan dalam analisis data di atas merupakan bagian yang tidak saling terpisahkan, sehingga saling berhubungan antara tahapan yang satu dengan yang lain. Analisis dilakukan secara kontinu dari awal sampai akhir 
penelitian, untuk mengetahui Konstruksi Informasi Politik pada Masyarakat Kota Cimahi Pasca Penetapan Calon Walikota dan Wakil Walikota dalam Pilkada Serentak 2017.

\section{HASIL DAN DISKUSI}

Informasi politik yang akan menguatkan pengetahuan politik serta implementasi partisipasi politik masyarakat merupakan hal fundamental untuk menggunakan hak-hak politiknya dalam menentukan pemimpin yang diinginkan dalam membangun kualitas demokrasi. Partisipasi politik mengacu pada kegiatan seseorang atau sekelompok orang secara sukarela untuk ikut serta aktif dalam kehidupan politik yaitu dengan jalan mengambil bagian dalam proses pemolihan penguasa atau mempengaruhi seleksi pejabat-pejabat negara dan/atau tindakan yang diambil oleh mereka dan secara langsung atauu tidak langsung mempengaruhi kebijakan pemerintah (Budiarjo, 2005:40).

Esensinya partisipasi politik masyarakat diperlukan untuk membangun keberadaban bernegara. Orang-orang yang melakukan golput juga ikut bertanggung jawab terhadap kehancuran bangsa. Fenomena golput memang selalu ada walaupun ada perbedaan di era Orde Baru dan era Reformasi. Pada masa Orba, ajakan golput adalah sebagai bentuk perlawanan politik, terhadap arogansi pemerintah yang dianggap tidak menjunjung asa demokrasi. Pada era reformasi yang lebih demokratis, pengertian golput adalah bentuk dan fenomena dalam demokrasi. Dari beberapa sisi, sikap golput adalah idealis. (Pikiran Rakyat, 2013). Komunikasi Politik melalui pendidikan politik merupakan kewajiban bagi penyelenggara dalam hal ini KPU Kota
Cimahi dan partai politik dalam memberikan informasi politik kepada masyarakat. Informasi politik yang didapat seperti halnya rekam jejak tiaptiap pasangan calon, visi dan misi, serta hal-hal mengenai bagaimana terselenggaranya Pemilihan Kepala Daerah, akan mempengaruhi partisipasi politik dan rasionalisasi pemilih untuk dapat berperan dalam suksesi Pemilihan Kepala Daerah yang digelar 15 Februari 2017. Menurut Bill Kovach dan Tom Rosenthiel (dalam Haryanto, 2010: 7), hak atas informasi merupakan hak dasar yang melekat pada manusia, atau sebagai kesadaran manusia untuk mengetahui hal - hal diluar dirinya.

Nimmo (dalam Muhtadi, 2008:21) mengenai keterlibatan politik seorang kandidat atau sekelompok orang dalam komunikasi politik sebagai berikut : Keterbukaan kepada komunikasi politik dapat mempengaruhi orang untuk secara aktif terlibat dalam politik disatu pihak, dan dipihak lain, komunikasi politik juga bisa menekan partisipasi politik, karena itu, manuver-manuver politik yang sering keluar dari sejumlah elit dan aktor politik pada umumnya, pada gilirannya dapat berimplikasi pada pembentukan perilaku individu dan kelompok yang terlibat dalam proses tersebut. Pesan-pesannya akan menjadi rujukan penting dalam mengambil tindakan-tindakan formal ataupun informal khususnya berkenaan dengan aktivitas politik.

\begin{tabular}{cccc}
\multicolumn{2}{c}{ Minimnya } & informasi & politik \\
menjadi hal & yang & sangat
\end{tabular}
mengkhawatirkan karena implikasinya pada keterlibatan masyarakat dalam membangun konsolidasi demokrasi lokal, begitupun dengan Kota Cimahi pada 15 Februari 2017 melaksanakan Pilkada Serentak. Menyoal hal tersebut penulis, melakukan penelitian pada 
tanggal 28 Oktober 2016 sampai 15 Januari 2017, dimana dalam temuannya tersebut sangat minimnya informasi politik yang didapat oleh masyarakat. Temuan tersebut hasil dari mewawancarai 330 informan dan melakukan observasi lalu kemudian diaktgorisasikan jawaban yang hampir sama dari informan mengenai pengetahuan pemilih tentang kapan pelaksanaan Pemilihan Wlikota Cimahi 2017 maka diperoleh hasil data dilapangan menjelaskan bahwa di posisi pertama sebanyak 67 persen (226 Informan) hanya mengetahui kapan diselenggarakannya pilkada serentak, tanpa mengetahui tanggal pasti untuk pencoblosannya, serta masyarakat pun hanya mengetahui kandidat pasangan calon tanpa mengetahui visi dan misi kandidat tersebut. Sementara pada posisi kedua, sebanyak 26 persen (90 Informan) tidak mengetahui akan diselenggarakannya Pilkada Serentak, termasuk tanggal pencoblosan dan hanya mengetahui pasangan calon tanpa mengetahui visi dan misi kandidat pasangan calon tersebut. Diposisi ke tiga terdapat 6 persen (20 Informan) masyarakat mendapat informasi mengenai Pilkada Serentak, bahwa mereka mengetahui ada 3 Pasangan Calon yang mengikuti kontestasi pilkada, dan salah satu kandidatnya (Incumbent), terkena tsunami politik dengan adanya Operasi Tangkap Tangan (OTT) oleh KPK. Sementara itu, 1 persen (4 Informan) yang mengetahui pilkada serentak baik itu tanggal pencoblosan, pasangan calon dan mengetahui salah satu visi dan misi kandidat tersebut.

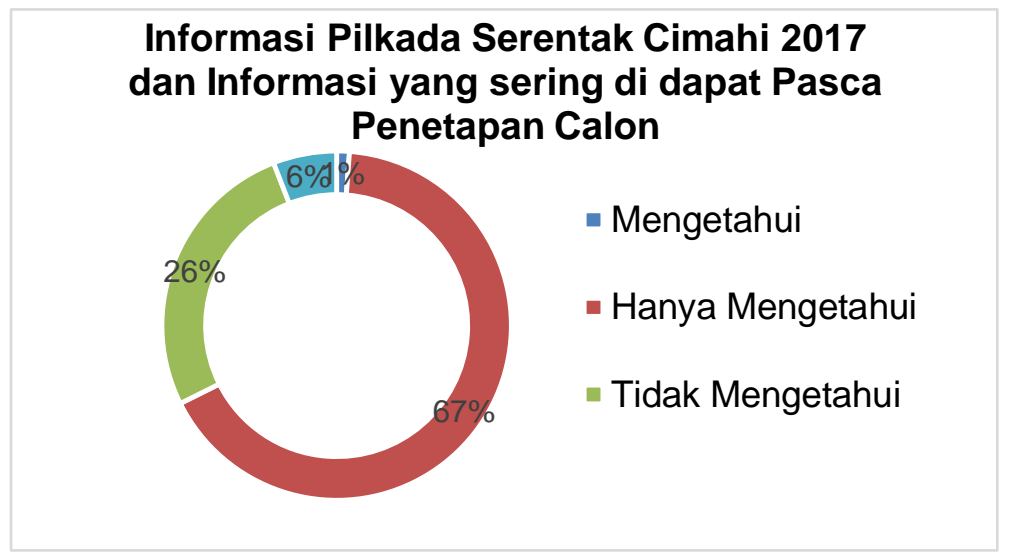

Sementara itu dalam hal sosialisasi yang dilakukan oleh Institusi penyelenggara pemilu KPU dan Partai Politik, dari data tersebut sebanyak $8 \%$ Institusi Penyelenggara Pemilu ataupun "beberapa" Partai Politik mengadakan acara sosialisasi mengenai Pilkada Serentak Cimahi 2017. Temuan dari data tersebut menjelaskan bahwa sosialisasi yang dilakukan institusi penyelenggara pemilu hanya mengenai tata cara pencoblosan, pemasangan spanduk, penyebaran pamflet Pilkada Serentak. Sementara, dari partai politik menyampaikan visi dan misi Pasangan Calon yang diusung. Itu pun hanya 1 kali saja. Selebihnya tidak ada informasi 
lagi terkait Pilkada Serentak 2017 di Kota Cimahi ini.

92\% mayoritas masyarakat di Cimahi belum meresakan adanya sosialisasi dari Institusi Penyelenggara Pemilu mapun Partai Politik. Dari data temuan dilapangan tersebut menjelaskan bahwa sosialisasi yang dilakukan oleh Institusi Penyelenggara Pemilu dan Partai Politik tidak merata. Sehingga berdampak pada masyarakat tidak mengetahui secara pasti kapan itu Pilkada serentak Cimahi dilaksanakan dan Visi - Misi pasangan Calon yang akan mengikuti konstestasi Pilkada Serentak tersebut.

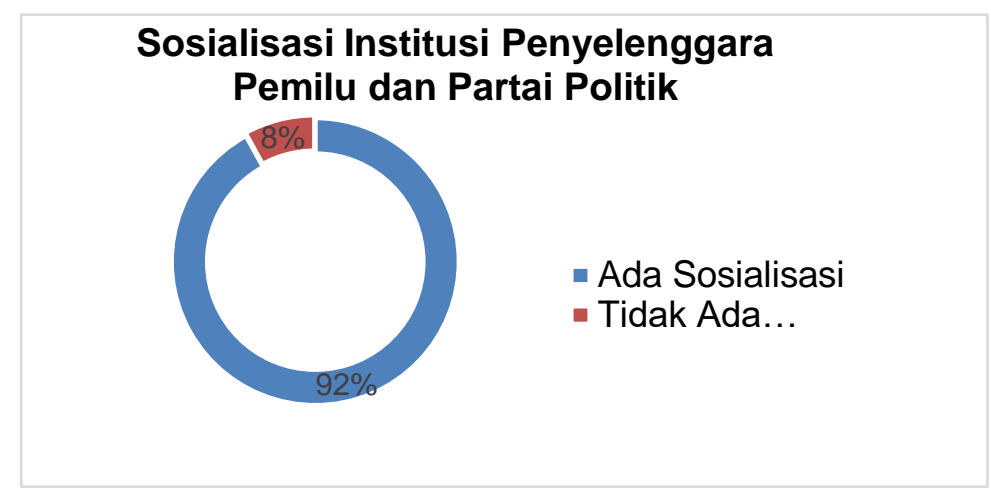

Dijelaskan dalam UndangUndang Nomor 8 Tahun 2015 Pasal 63 ayat 1 bahwa Kampanye dilaksanakan sebagai wujud dari pendidikan politik masyarakat yang dilaksanakan secara bertanggung jawab. Dalam Pasal 64 Undang-Undang No. 8 Tahun 2015 pun disebutkan bahwa pasangan calon wajib menyampaikan visi dan misi yang disusun berdasarkan Rencana Pembangunan Jangka Panjang Daerah Provinsi atau Rencana Pembangunan Jangka Panjang Daerah Kabupaten/Kota secara lisan maupun tertulis kepada masyarakat. Penyampaian materi Kampanye dilakukan denga cara yang sopan, tertib, dan bersifat edukatif. Kemudian pada Pasal 65 disebutkan bahwa Kampanye dapat dilaksanakan melalui; a. pertemuan terbatas; $b$ pertemuan tatap muka dan dialog; c. Debat publik/debat terbuka antar pasangan calon; d. Penyebaran bahan Kampanye kepada umum; e.
Pemasangan alat peraga; f. Iklan media massa cetak dan elektronik; dan/atau g. Kegiatan lain yang tidak melanggar larangan Kampanye dan ketentuan peraturan peruandang-undangan.

Menurut Doris Graber (Cangara, 2011) menyatakan bahwa komunikasi politik tidak hanya retorika, tetapi juga mencakup simbol-simbol bahasa, seperti bahasa tubuh serta tindakantindakan politik misalnya boikot, protes dan unjuk rasa. Dengan demikian maka komunikasi politik dapat diartikan sebagai proses penciptaan symbol dan lambang yang berisi pesan politik dari seorang, kelompok, atau lembaga kepada orang lain, kelompok atau lembaga untuk membuka wawasan atau cara berpikir, sehingga membentuk sikap dan perilaku tertentu seperti yang ditargetkan. Oleh karena itu komunikasi politik berimplikasi dan memiliki konsekuensi pada aktivitas politik. Informasi politik masyarakat bisa 
membangun pemahaman dan cara pandang dalam melihat objek politik, apa yang dikatakan Surbakti bahwa orientasi politik sebenarnya merupakan suatu cara pandang dari suatu golongan masyarakat dalam suatu struktur masyarakat. Timbulnya orientasi itu dilatarbelakangi oleh nilai-nilai yang ada didalam masyarakat maupun dari luar masyarakat yang kemudian membentuk sikap dan menjadi pola masyarakat tersebut untuk memandang suatu objek politik. (Surbakti, 1992: 140). Cara pandang masyarakat tersebut, meurut hemat peneliti mampu didorong dengan usaha komunikasi politik dari kandidat yang serius dalam mendorong hal tersebut.

Mencermati hal tersebuat sudah seharusnya bahwa komunikasi politik melalui kampanye menjadi bagaian pasangan calon dapat berlomba-lomba menyampaikan visi dan misi yang di usung untuk merebut hati publik. Baik itu Kampanye dengan menggunakan pesan verbal maupun non verbal. Terlebih lagi dalam even-even tertentu penguasaan bahasa verbal baik itu lisan ataupun tulisan menjadi faktor yang mendukung ketertarikan pemilih terhadap calon kepala daerah dan wakil kepala daerah. Kampanye dengan komunikasi non-verbal pun tidak kalah penting. Pesan non-verbal yang disampaikan oleh komunikator kepada komunikan (masyarakat/khalayak) memiliki pengaruh cukup signifikan kepercayaan umum yang muncul bahwa gerakan tubuh,

ekspresi wajah, vokal, gerakan isyarat non-verbal lainnya dapat menafsirkan makna tertentu. Dan pada realitasnya, setiap pasangan calon Kepala Daerah dan Wakil Kepala daerah memberi penguatan khusus pada pesan non-verbal tertentu.

Kampanye menjadi momentum untuk pasangan calon Kepala Daerah dan Wakil Kepala Daerah untuk menyampaikan visi dan misi kepada masyarakat untuk merebut hati publik. Namun, pada penelitian ini mayoritas masyarakat di Kota Cimahi hampir tidak mengetahui visi dan misi Pasangan Calon Pilkada Serentak Cimahi 2017. Hanya $5 \%$ yang mengetahui visi dan misi pasangan calon, itu pun karena hubungan kedekatan dengan tim sukses beberapa kandidat ataupun pendukung dari pasangan calon tersebut. Sementara 95 $\%$ masyarakat tidak mengetahui visi dan misi dari Pasangan Calon yang mengikuti kontestasi Pilkada Serentak 2017 Cimahi. Kurangnya sosialisasi dari masing-masing kandidat, partai pengusung, maupun institusi penyelenggara pemilu menyebabkan kurangnya pengetahuan masyarakat akan visi dan misi dari pasangan calon. karena

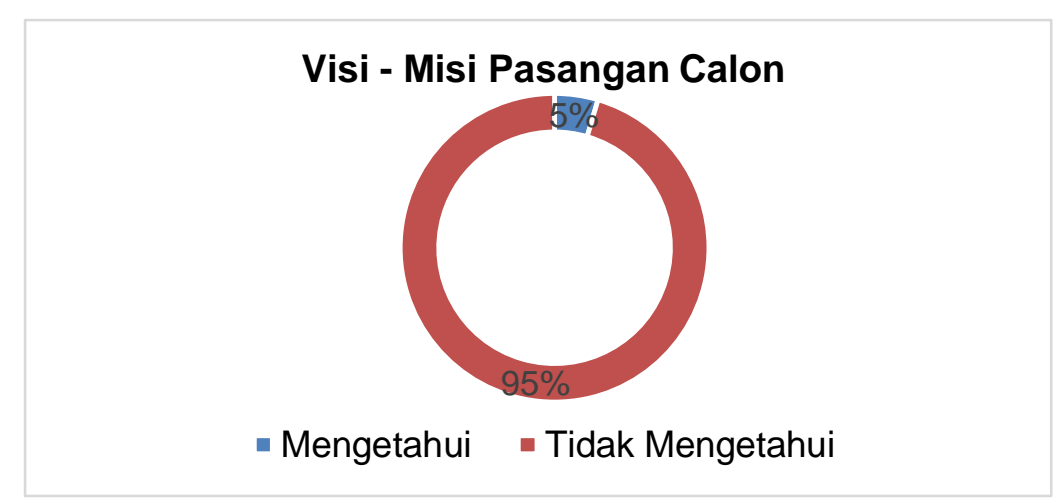


Dalam Undang-Undang Nomor 14 tahun 2008 tentang Keterbukaan Informasi Publik tercantum pada Bab I Pasal 1 ayat 1 dan 2 yang menyatakan informasi sebagai keterangan, pernyataan, gagasan, dan tanda-tanda yang mengandung nilai, makna, dan pesan, baik data, fakta maupun penjelasannya yang dapat dilihat, didengar, dan dibaca yang disajikan dalam perkembangan teknologi informasi dan komunikasi secara elektronik maupun nonelektronik. Informasi Publik adalah informasi yang dihasilkan, disimpan, dikelola, dikirim, dan/atau diterima oleh suatu badan publik yang berkaitan dengan penyelenggara dan penyelenggaraan negara dan/atau penyelenggara dan penyelenggaraan badan publik lainnya yang sesuai dengan UndangUndang ini serta informasi lain yang berkaitan dengan kepentingan publik.

Dengan demikian pemahaman tentang informasi politik mengacu pada definisi tersebut dengan menekankan pada konten politik. Media massa merupakan sarana paling efektif digunakan untuk menyebarkan dan menjaring informasi politik. Dalam hal ini media bukan saja sebagai sumber informasi politik melainkan kerap menjadi faktor pendorong (trigger) terjadinya perubahan politik (Suwardi,2004).

Disamping itu media memiliki potensi mentransfer dan mengekspos informasi politik bagi pembentukan opini publik. Keikutsertaan media dalam membentuk opini publik merupakan upaya membangunkan sikap dan tindakan khalayak mengenai sebuah masalah politik dan/atau aktor politik. Dalam kerangka ini media menyampaikan pembicaraan-pembicaraan politik kepada khalayak. Bentuk pembicaraan politik tersebut dalam media antara lain berupa teks atau berita politik yang di dalamnya terdapat pilihan simbol politik dan fakta politik. Karena kemampuan ini pula media massa sering dijadikan alat propaganda dalam komunikasi politik. Selain menjadi sumber informasi, media massa juga merupakan saluran komunikasi bagi para aktor politik. Cara- cara media menampilkan peristiwa- peristiwa politik dapat mempengaruhi persepsi para aktor politik dan masyarakat mengenai perkembangan politik. Melalui fungsi kontrol sosialnya, bersama institusi sosial lainnya, secara persuasif media massa bisa menggugah partisipasi publik untuk serta dalam merombak struktur politik.

Media dalam komunikasi politik kontemporer digunakan untuk membedakan produk politik (partai politik dan kandidat) (McNair, 2011:6). Konsep ini berbeda dengan proses komunikasi politik tradisonal, karena dalam komunikasi politik kontemporer terjadi proses komunikasi dengan sistem pertukaran informasi, ideologi, sistem nilai, norma dan budaya di masyarakat yang terbuka (Firmanzah, 2008:7). Sementara itu, dalam penelitian ini, media yang paling banyak digunakan dalam Sosialisasi Pilkada Serentak baik itu dari Institusi penyelenggara Pemilu maupun Partai Politik yaitu Baliho, Pamflet. Dalam penelitian ini, masyarakat mendapatkan informasi mengenai Pilkada Serentak 2017 Cimahi selain dari ke dua media tersebut (Baliho, pamflet), Masyarakat mencari informasi seputar Pilkada 
Serentak ini dari Surat kabar sebanyak (20\%), Radio (9\%), Televisi (7\%), Internet (4\%). Presentase internet lebih kecil dari media lainnya karena, tidak semua masyarakat bisa mengakses internet.

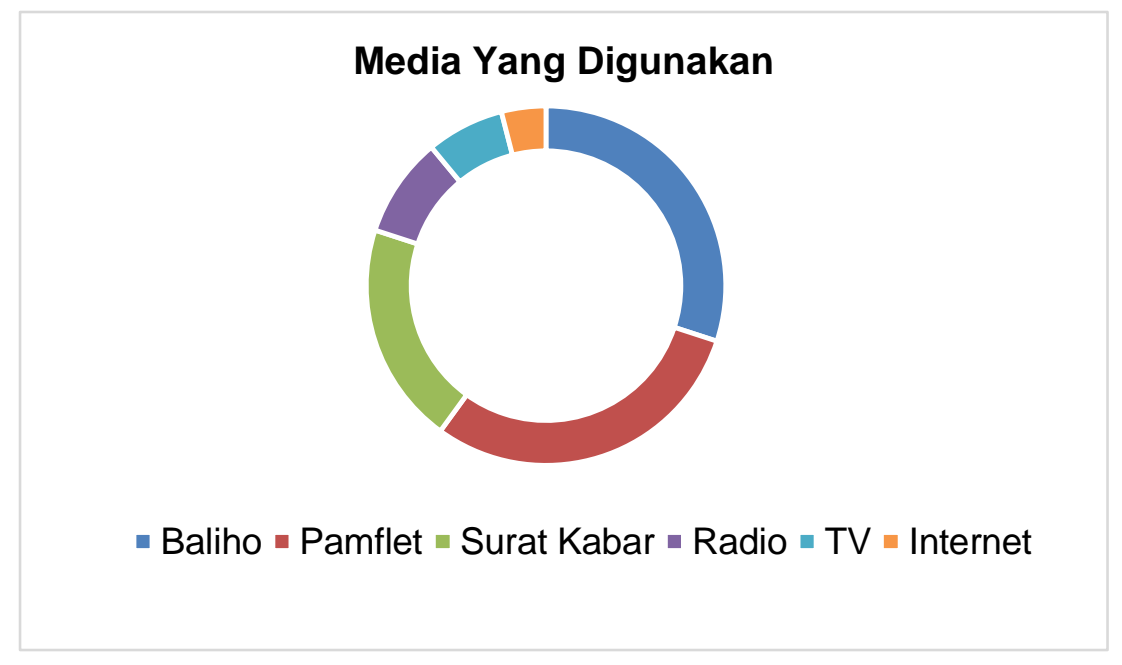

\section{SIMPULAN}

Berdasarkan hasil penelitian yang telah dibahas mengenai Konstruksi Informasi Politik (Studi Kasus Pada Masyarakat Kota Cimahi Pasca Penetapan Calon Walikota Dan Wakil Walikota Dalam Pilkada Serentak) Hasil tersebut dapat disimpulkan bahwa jangan mengharapkan demorasi lokal berjalan dengan baik ketika masyarakat menjadi objek dan dieksploitasi kedaulatannya. Muara konsolidasi demokrasi lokal bisa terwujud ketika informasi politik yang diberikan oleh institui penyelenggara pemilu dan institusi partai politik, dapat mendorong rakyat untuk belajar tentang politik karena relasinya pada pengetahuan politik rakyat itu sendiri, preverensi dan evaluative dalam hal ini menjadi pemilih rasional. Paling tidak kecenderungan irrasional dalam memilih hendaknya dapat dihindari melalui pendidikan politik yang secara intensif dilakukan oleh institusi penyelenggara pemilu juga oleh partai politik untuk membuktikan komitmennya kepada masyarakat hingga tidak enggan untuk berpartisipasi dalam kehidupan politik dan kenegaraan.

Tidak hanya eksploitasi

kedaulatan rakyat karena logika elit politik baik partai politik (Parpol) beserta calonnya maupun calon dari jalur perseorangan dan instutusi penyelenggara pemilu belum mampu melakukan proses komunikasi politik yang sewajarnya, karena Pilkada Serentak harus terpenuhinya informasi politik pemilih, baik itu dari institusi penyelenggara pemilu dan institusi politik, karena pilkada serentak bagian dari bagaimana kandidat berlombalomba dalam memberikan informasi politik mengenai prospective policy choices. Bukan hanya sekedar pemenuhan demokrasi prosedural pada tingkat lokal (Provinsi dan Kabupaten/Kota) semata. Melaikan suatu proses pemilian kepala daerah 
dengan memanfaatkan sumber daya politik; yaitu partisipasi masyarakat dalam memberikan hak suaranya kepada pemimpinnya kedepan. Sehingga, usaha yang dilakukan harusnya setelah penetapan Pasangan calon dan setelah kampanye terbuka harusnya terpenuhinya kebutuhan informasi politik masyarakat sehingga

\section{DAFTAR PUSTAKA}

Arifin, Anwar. 2011 Komunikasi Politik (Paradigma, Teori, Aplikasi, Strategi Komunikasi Politik Indonesia). Jakarta : PT. Balai Pustaka.

Budiarjo, Miriam. 2005. Dasar-Dasar Ilmu Politik. Jakarta : PT. Gramedia.

Cangara, Hafied. 2011. Komunikasi Politik. Konsep, Teori dan Strategi. Jakarta: Rajawali Press

Creswell J.W. 1998. "Qualitative Inquiry and Research Design: Choosing Among Five Traditions" by J. W. Creswell.

$\begin{array}{llr}\text { Kualitatif \& Desain } & \text { Riset: } \\ \text { Memilih diantara } & \text { lima } \\ \text { pendekatan. Yogyakarta : Pustaka } & \\ \text { Pelajar. } & & \\ \text { Firmanzah 2008. Marketing Politik. }\end{array}$

Firmanzah. 2008. Marketing Politik: Antara Pemahaman dan Realitas. Jakarta : Yayasan Obor Indonesia.

-------------.2010. Mengelola Partai
Politik: Komunikasi dan Positioning, Ideologi Politik di Era Demokrasi : yayasan Obor Indonesia.

Gazali, Effendi. 2004. Pemuda, Demokrasi \& Pendidikan Politik : Tinjauan Komunikasi Politik , Jakarta : Departemen Ilmu Komunikasi, Universitas Indonesia. masyarakat memilih dengan tanggung jawab besar secara rasional, dalam artian rakyat memilih kandidat pemimpin di daerahnya berdasarkan pertimbangan-pertimbangan yang akan "menguntungkan" kepentingan rakyat itu sendiri.

Haryanto, I. (2010). Media di bawah dominasi modal: ancaman terhadap hak atas informasi" dalam azasi. Edisi Maret - April 2010

Hamad, Ibnu. 2004. Konstruksi Realitas Politik dalam Media Massa. Jakarta : Granit.

Kumolo, Tjahyo dan Tim. 2017. Nawa Cita Untuk Kesejahteraan Rakyat Indonesia. Integrasi Perencanaan Pembangunan Nasional dan Daerah. Jakarta : PT. Kompas Media Nusantara.

McNair, B. 2010. An Introduction to Political Communication. Oxon, Canada:Routledge .

Muhtadi, Asep Saeful, 2008. Komunikasi Politik Indonesia. Bandung : Rosdakarya.

Surbakti, Ramlam. 1992. Memahami Ilmu Politik. Jakarta : Grasindo.

\section{Jurnal/Karya Ilmiah}

Sasmita, Siska. 2011. Peran Informasi Politik Terhadap Partisipasi Pemilih Pemula dalam Pemilu/Pemilukada. Jurnal Ilmiah Administrasi Publik dan Pembangunan, Vol.2, No.1, Januari-Juni 2011. ISSN : 20870825. Universitas Negeri Padang.

Sandra, Lidya Joyce. 2013. Political Branding Jokowi Selama Masa Kampanye Pemilu Gubernur DKI Jakarta 2012 di Media Sosial 
Twitter. Jurnal E-Komunikasi Vol

I. No.2 Tahun 2013. Universitas Kristen Petra Surabaya.

Surayatna, Undang. 2007. Hubungan Karakteristik Pemilih Dan Terpaan Informasi Kampanye Politik Dengan Perilaku Memilih (Kasus Pemilihan Bupati Dan Wakil Bupati Cianjur Tahun 2006). Tesis. Institut Pertanian Bogor.

\section{Undang-Undang atau Peraturan}

Undang-Undang Nomor 14 Tahun 2008 Tentang Keterbukaan Informasi Publik menyatakan informasi sebagai keterangan, pernyataan, gagasan, dan tanda-tanda yang mengandung nilai, makna, dan pesan, baik data, fakta maupun penjelasannya yang dapat dilihat, didengar, dan dibaca yang disajikan dalam perkembangan teknologi informasi dan komunikasi secara elektronik maupun nonelektronik.

Undang-Undang Nomor 8 Tahun 2015 Tentang Perubahan atas undangundang Nomor 1 Tahun 2015 tentang penetapan peraturan pemerintah pengganti UndangUndang Nomor 1 Tahun 2014 Tentang Pemilihan Gubernur,
Bupati dan Walikota menjadi Undang-Undang.

\section{Biodata Penulis}

Adiyana Slamet, lahir di indramayu, 19 Mret 1981, pendidikan dari SD sampai SMA di selesaikan ditempat kelahirannya, lalu meneruskan Kuliah S1 di Hubungan Internasional FISIP Unpas, S2 di Program Pascasarjana Ilmu Komunikasi UNPAD dan sekarang sedang menyelesaikan S3 di Program Doktoral Pascasarjana Ilmu Komunikasi Unpad, konsentrasi yang diambil Komunikasi Politik, aktivitas selama ini menjadi Dosen di Program Studi Ilmu Komunikasi FISIP Unilom dan dosen Luar Biasa di FISIP UNPAS, selain itu Adiyana mendirikan Lingkar Kajian Komunikasi\&Politik Indonesia (LKKP), serta aktiv menulis di beberapa surat Kabar seperti Pikiran Rakyat dan Sindo Jabar, dan juga aktif mengisi beberapa Program TV nasional maupun Lokal, dan talkshow di beberapa Radio Elshinta Bandung dan PRFM, selain itu juga aktif mengisi semniar-seminar mengenai Komunikasi Politik di beberapa Lembaga institusi Penyelenggara Pemilu, Kampuskampus dan Partai Politik di Jawa Barat. 